\title{
INTERLINEAR GLOSSING IN A HISTORICAL PERSPECTIVE: A CASE OF GRADIENCE IN THE PASSIVE VOICE IN JAPANESE ${ }^{1}$
}

This paper examines cases where our common practice of interlinear glossing can be misleading in decoding typological data. Particular attention is paid to the Japanese passive voice, where the suffix -(r)are is believed to mark the passive voice. However, due to its polysemous nature, a previous assumption should be questioned. A hint can be found in its historical development, which can leave some residues forming gradience. Prescriptive grammar has been written at least partially for educational purposes, but the way it treats grammar sometimes obscures what an internal structure is really like. This paper also shows that a typological comparison can add valuable elements in discussing grammar in a single language.

Key words: interlinear glossing, passive voice, middle voice, typology, gradience, grammaticalisation

\section{Introduction}

This paper investigates possible danger lurking in the use of interlinear glossing. This practice has been very common in linguistic analysis, but there are cases where our analysis is misled by the glossing obscuring what a construction really is. To illustrate such cases, the passive voice in Japanese is used as an example. The passive morpheme is multifunctional,

\footnotetext{
junichitoyota@gmail.com

1 The abbreviations used in this paper are as follows: $\mathrm{ACC}=$ accusative; $\mathrm{CONJ}$ = conjunction; $\mathrm{COP}=$ copula; $\mathrm{DAT}=$ dative; FOC = focus; $\mathrm{GEN}=$ genitive; $\mathrm{MASC}=$ masculine; $\mathrm{MID}=$ middle; $\mathrm{NEG}=$ negative; $\mathrm{PASS}$ = passive; $\mathrm{PL}=$ plural; $\mathrm{POT}=$ potential; $\mathrm{PRS}=$ present $\mathrm{PRT}=$ participle; $\mathrm{PST}=$ past $\mathrm{Q}=$ question particle; $\mathrm{SG}=$ singular; $\mathrm{SUBJ}=$ subjunctive; TOP = topic.
} 
but with a closer examination, it is possible to see that both the passive and middle voice are involved under what has been considered as the passive. This point can be made clear once typological comparison and historical development are taken into consideration. Note that dominance of certain languages in linguistic analysis is also examined in relation to the typological comparison. Thus, what has been commonly known can be questioned and possibly given a new interpretation.

This paper is organised as follows:diversity concerning the Japanese passive is demonstrated first, followed by possible influence of dominant languages on description of a target language. Facing these problems, it is argued that a historical analysis is necessary to see if a gradience is involved in a target construction and if historical residues are present.

\section{Variations of the passive voice in Japanese and interlinear glossing}

It has been known that the passive voice in Japanese carries various functions, which are well-documented in previous research. Toyota (2011: 11-29) gives a comprehensive overall view and lists five types under the term passive, which are: verbal passive, adversative passive, spontaneous passive, potential passive, and honorific passive. These five types are considered as variations of the passive here. Also, note that comparison is made with Indo-European languages in order to highlight subtle meaning differences in the Japanese passive.

Verbal passive in (1) is more or less identical in function to the passive voice among the Indo-European languages such as English. This type emerged through translation from Dutch (Kinsui 1998), and the use of the case marker -niyotte 'by means of' was in particular created in order to cope with the agent phrase that appeared in the Dutch counterpart headed by a preposition door 'through'(cf. (10)).Adversative passive, as shown in (2), is often used as a special usage of the passive in typological works (cf. Toyota 2007). It is often not overtly expressed, but the sufferer here is a speaker, and in some dialects of English, it is often expressed with on as in Someone built a tall building in front of my house on me. Among the Indo-European languages, a sufferer is sometimes expressed in the dative case, known as ethical dative, as exemplified in (3) and (4) from Serbian. (3b) shows the use of the dative experiencer, which specifically 
INTERLINEAR GLOSSING IN A HISTORICAL PERSPECTIVE: A CASE OF ...

implied annoyance or suffering by the part of experiencer. This is absent in the unmarked nominative counterpart in (3a), and the case marking can be easily altered. However, (4) exemplifies a case where a dative can be added to an unmarked clause. (4b), in comparison with (4a), contains an extra argument, nam 'to us', a dative form of $m i$ 'we.' Thus, ethical dative can be an additional argument, rather than alternation of case marking. Japanese expresses this by the use of the passive voice.

Verbal passive
(1) Kare-wa
ookuno hito-ni
hinans-are-ta
he-TOP
many people-DAT
criticise-PASS-PST
'He was criticised by many people.'

Adversative passive
(2) Ie-no mae-ni takai-buru-wo tater-are-ta House-GEN front-at tall-building-ACC build-PASS-PST 'I was adversely affected by someone's building a tall building in front of my house.'

Serbian
a. Ja sam hladan
I am cold.MASC.SG
'I am cold.'
b. Meni je hladno
I.DAT is cold
'I am cold/I feel cold.' (ethical dative, lit .'to me is cold')

Serbian

(4)
a. Beba
plače noću
baby
cry.3SG at.night
'The baby cries at night.'
b. Beba
nam plače
baby
us.DAT
cry.3SG
noću
'The baby cries at night to us.' (i.e. 'for our detriment')

The other three types may be given different terms in previous research, and some are typologically rare under the category of the passive. 
Spontaneous passive in(5) denotes that an event occurs spontaneously without outer cause. This is contrary to the canonical passive voice, since the canonical passive is expected to possess a high degree of transitivity (cf. Toyota 2012), especially transitivity based on semantic distinctions as found in Hopper and Thompson (1980) and Taylor (2003). Potential passive, as its name suggests, denotes possibility, and it often appears in the negative clause, as shown in (6). Its affirmative counterpart in (7) often has a potential marker $-e$, which is a result of sound reduction or erosion in the course of grammaticalisation of the passive marker - $(r)$ are, and only the final vowel was left. Thus, negation and potential passive are functionally closely intertwined. The last type, honorific passive, carries the passive morpheme, but it acts as an active voice. Thus, without sociocontextual clues, examples like (8) can be read as either honorific passive or verbal passive.

Spontaneous passive
Mukashi-ga
shinob-are-ru
old.time-FOC remember-PASS-PRS

'Memories of old time spontaneously come into my mind.'

Potential passive

(6)
Yuujinn-wa
kaigou-ni
ik-are-nai
friend-TOP meeting-DAT go-PASS-NEG
'My friend cannot attend a meeting.'
(7) Yuujinn-wa kaigou-ni ik-e-ru friend-TOP meeting-DAT go-POT-COP.PRS
'My friend can attend a meeting.'

Honorific passive

(8)
kyoujyu-ga
waraw-are-ta
professor-FOC
laugh-PASS-PST
'A professor smiled.' (honorific passive)
'A professor was laughed at.' (verbal passive)

In discussing the passive voice, valency alternation, undergoer's affectedness, agent defocusing and the subject animacy are often 
discussed. The passive voice involves the valency reduction, and the actor in the active clause is relegated to outside of its core argument structure. Due to this, it is commonly assumed that monovalent verbs cannot be passivised. However, due to the semantic-oriented transitivity, monovalent verbs can be passivised, as exemplified from Icelandic in (9) and Dutch in (10). Icelandicdansa'dance' and Dutch fluiten 'whistle' are both monovalent verbs. Among the five types of the construction described so far, only verbal passive behaves within the common definition of the passive concerning the verbal valency. Spontaneous and potential passive can have the valency reduction with the monovalent verbs, but there is no change when monovalent verbs are used. In addition, adversative passive always increases the number of argument, and this is a typical syntactic characteristics of the causative, not the passive.

\section{Icelandic (Thráinsson 1994: 179) \\ Баð hefur áreiðanlega \\ there have.PRS.3SG certainly \\ verið \\ dansað \\ $b a ́$ \\ 'There has certainly been dancing.' (lit. 'there has certainly been danced)}

Dutch

(10) $\mathrm{Er}$

It

wordt

door

de jongens

gefloten

'There is whistling by the boys.'

The passive has been known to have the function of agent defocusing or impersonalisation (cf. Shibatani 1985), whereby the identity of actor is supressed, either intentionally or its identity is not known. This is true in all types of the passive except honorific passive. Thus, the morpheme $-(r)$ are seems to be closely associated with obscuring the identity of actor. As for the undergoer's affectedness, the passive subject is normally supposed to undergo much influence from an event, and the affectedness should be very high. However, it is only observable in the verbal and adversative passive. When energy transfer is considered in terms of the semanticoriented transitivity, the lack of affectedness shows the low degree of transitivity, which is an counter examples to (9). Such intransitive clauses can carry the passive morpheme in Japanese. And concerning the subject animacy, the passive voice normally has the dominant inanimate subject 
(cf. Toyota 2008: 117-118), and only the verbal and spontaneous passive fit in this pattern. The adversative and honorific passive show the preference for human subject, and potential passive tend to accommodate both human and inanimate subjects. These patterns are summarised in Table 1.

Table 1. Summary of characteristics of the Japanese passive (based on Toyota 2011: 57)

\begin{tabular}{|l|l|l|l|l|l|l|}
\hline \multicolumn{2}{|c|}{} & VERB & ADV & SPON & POT & HON \\
\hline \multirow{4}{*}{ Valency } & Increase & - & $\sqrt{ }$ & - & - & - \\
\cline { 2 - 8 } & Decrease & $\sqrt{ }$ & - & $\sqrt{ }$ & $\sqrt{ }$ & - \\
\cline { 2 - 8 } & No change & - & - & - & - & $\sqrt{ }$ \\
\hline \multirow{2}{*}{$\begin{array}{l}\text { Number of } \\
\text { Argument }\end{array}$} & Monovalent & - & $\sqrt{ }$ & $\sqrt{ }$ & $\sqrt{ }$ & $\sqrt{ }$ \\
\cline { 2 - 8 } Agent defocus & Di/trivalent & $\sqrt{ }$ & $\sqrt{ }$ & $\sqrt{ }$ & $\sqrt{ }$ & $\sqrt{ }$ \\
\cline { 2 - 8 } & Aresent & $\sqrt{ }$ & $\sqrt{ }$ & $\sqrt{ }$ & $\sqrt{ }$ & - \\
\hline \multirow{2}{*}{ Affectedness } & Present & - & - & - & - & $\sqrt{ }$ \\
\cline { 2 - 8 } & Absent & - & - & $\sqrt{ }$ & - & - \\
\hline \multirow{2}{*}{ Animacy } & Human & - & $\sqrt{ }$ & - & $\sqrt{ }$ & $\sqrt{ }$ \\
\cline { 2 - 8 } & Inanimate & $\sqrt{ }$ & - & $\sqrt{ }$ & - & - \\
\hline
\end{tabular}

\section{Glossing practice and grammatical description}

Verbal passive is close to the typologically common passive. As easily observable from Table 1, none of the other types resembles verbal passive. Others possess different grammatical features that should belong to other constructions such as the causative or the middle voice. In spite of this, all five types of constructions are collectively termed as the passive. The Japanese grammar has gained much attention during the 80s' when search for linguistic universal found a momentum, and its linguistic interpretation might have gone through the influence of English, which is the language of description in linguistics. In other words, the English passive is translated as verbal passive in Japanese, and since the structure contains the morpheme - $(r)$ are, any structures with this morpheme was blindly treated as passive. However, in former studies, both descriptive and theoretical, the morpheme-(r)are has been classified under the passive, and this is applicable to both modern Japanese and Classical Japanese. Thus, this treatment of the passive morpheme has been the same, and what we see in modern linguistics is derived from traditional studies in grammar. 
However, the grammar, not its description, has been influenced by the language contact, i.e. translation from Dutch, as mentioned earlier. What is interesting is that Dutch does not have the fully-fledged passive voice (cf. Toyota 2009a for the comparison among the Germanic languages), and its interpretation is heavily influenced by the English grammar. Once the structure is seen in a wider perspective, it soon becomes obvious that what appears to be the passive in Dutch is in fact a perfective aspectual structure. A periphrastic passive or passive-like construction in the IndoEuropean languages is normally terms as passive, due to the influence of the English language, but this is misleading without taking the tenseaspectual patterns into consideration (Toyota and Mustafović 2006). This is the tip of the iceberg, and it is often the case that one dominant language, either politically or academically, becomes a means of communication, it unknowingly influences other languages. In recent years, English is the dominant language in academia, and Anglo-centrism is often a cause of the problem, since the English grammar is a base for descriptive grammar for other languages.

What is interesting is that English went through the same demise earlier, as Latin used to be the dominant language until the $18^{\text {th }}$ century and was influential in making a prescriptive grammar when the standardisation of English was in progress. Latin was once the language of the bible and it was given a special status among the educated people. One of the most obvious change is the loss of double negation in earlier English. The structure was very common earlier, i.e. "[i]n Old English negatives tended to accumulate in a sentence, reinforcing each other. Multiple negatives are also frequent in Chaucer and Shakespeare's work, and in later writers too" (Cheshire 1998: 119).Due to the influence from the widespread knowledge of Latin among the educated in Britain, an earlier common double negation, as in I don't have no book, was frown upon. This form of negation is still visible in various dialectal forms, i.e. "[e] ven in the very modern spoken component of the BNC, the occurrence of negative concord for some dialect regions ranges as high as 33 per cent" (Anderwald 2002: 115). However, "[d]ouble negatives were roundly condemned as illogical because it was said, on the model of Latin, that two negatives made a positive" (Blake 1996: 264). Some of the earlier reference grammar also referred to this, i.e. "[t]wo Negativesin English destroy oneanother, or are equivalent to an affirmative" (Lowth 1763). 
Junichi Toyota

Thus, the double negation seems to be a concern for many people in the $18^{\text {th }}$ and $19^{\text {th }}$ century Britain.

As scientific thinking gained firm foothold among the educated after Newton, mathematical thinking became a central part in academic matters, including grammar. As Jones and Ereira (2005: 115) states, "[t]he natural philosophers of the Middle Ages floundered in ignorance and superstition until Newton changed the study of the world by basing his investigations on experiments and mathematics." This made people's mindset more towards scientific, analytical thinking, and linguistically, this was most vividly observable in the negation.

Influence of our common misunderstanding is grave, and the treatment of the passive voice is a good example. Various factors can be held responsible for this, but when one takes into consideration historical development and gradient nature of changes, the passive voice can be seen in a new, more comprehensive light.

\section{Possible resolution: origin, historical development and continuum}

By comparing these features in Table 1, each type has its own pattern and none of them is identical. However, verbal passive is similar to spontaneous passive, differing in the passivisation of monovalent verbs and the absence of affectedness of undergoer. Honorific passive, on the other hand, differs in all five features. Therefore, none of these types are identical. The differences between verbal passive and the rest can also alert a warning and raise a question as to how to handle this morpheme.

The passive morpheme is polysemous in nature, meaning that they are historically somehow related. Verbal passive in Japanese developed from spontaneous passive, and during the Old Japanese period, potential passive was also frequent. Honorific passive followed these, andverbal passive gained high frequency in use in the $17^{\text {th }}$ century. Adversative passive emerged even later, around the mid $19^{\text {th }}$ century. The chronology is summarised in Table 2. 
INTERLINEAR GLOSSING IN A HISTORICAL PERSPECTIVE: A CASE OF ...

Table 2. Chronology of different types in the Japanese passive

\begin{tabular}{|l|l|l|l|l|l|}
\hline & SPON & VERB & POT & HON & ADV \\
\hline $\begin{array}{l}\text { Old Japanese } \\
(700-800)\end{array}$ & $\sqrt{ }$ & $(\sqrt{ })$ & $\sqrt{ }$ & $(\sqrt{ })$ & \\
\hline $\begin{array}{l}\text { Late Old Japanese } \\
(800-1200)\end{array}$ & $\sqrt{ }$ & $(\sqrt{ })$ & $\sqrt{ }$ & $\sqrt{ }$ & \\
\hline $\begin{array}{l}\text { Middle Japanese } \\
(1200-1600)\end{array}$ & $\sqrt{ }$ & $(\sqrt{ })$ & $\sqrt{ }$ & $\sqrt{ }$ & \\
\hline $\begin{array}{l}\text { Early Modern Japanese } \\
(1600-1850)\end{array}$ & $(\sqrt{ })$ & $\sqrt{ }$ & $\sqrt{ }$ & $\sqrt{ }$ & \\
\hline $\begin{array}{l}\text { Modern Japanese } \\
(1850-\text { Present })\end{array}$ & $(\sqrt{ })$ & $\sqrt{ }$ & $\sqrt{ }$ & $\sqrt{ }$ & $\sqrt{ }$ \\
\hline
\end{tabular}

The suffix itself is believed to have been derived from a verb of existence, aru 'exist' (cf. Yamaguchi et al. 1997: 56; Sanson 1946: 160). The morpheme had already been firmly established, and its origin may be somewhat speculative, but the strongest evidence in support of this origin is that the earlier occurrences mainly denoted spontaneous reading, which is in essence closer to existential clause. Due to the nature of the existential verb, no intention of actor is implied, and the degree of affectedness on the undergoer is very minimum. The examples in (11) to (13) illustrate earlier cases of spontaneous passive. Yamaguchi et al. (1997:56) also refer to this point, claiming that the morpheme was originallyused to express a spontaneous event, which happened without any volitional action by actor. In terms of discourse function, spontaneous passive often builds up background information involving the introduction of a new referent into the context.The frequency of spontaneous reading dramatically dropped during the Early Modern Japanese period (cf. Table 2). Considering the chain of grammaticalisation, various internal semantic changes happened after Old Japanese, and the formation of verbal passive is relatively recent.
(11) Kyou-ha
kyou-nomizo
omohiy-are-ruru
today-FOC
city-only
think.of-PASS-PRS
'I cannot help (spontaneously) thinking about the city today.' (c.934
Tosanikki) 
Junichi Toyota

(12) Sayauno tokoro-nite-koso yorozu-ni kokorotukahiser-are-ru thar point-at-even all-DAT care-PASS-PRS 'In a situation like that, one comes to attend to every detail.' (c.1330 Tsurezuregusa)

(13) Noki chikaki togi-no imiziku kaze-ni kuk-are-te eaves near reeds-GEN hard wind-DAT blow-PASS-CONJ kudake-madofu-ga ito ahare ni-te break-tremble-TOP very pitiful COP-CONJ 'I feel pity to see common reeds near the eaves blown hard and falling around.' (c.1000 Sarashina Nikki)

Previous research (e.g. Matsumura and Sakanashi 1986; Kinsui 1997, among others) show that the subject in earlier Japanese passive, regardless of its type,is predominantly human animate. One such instance from Old Japanese is shown in (14). One may note that its reading is more spontaneous than volitional, i.e. there is no clear outer cause. Even when the actor is overtly expressed, as in (13), the degree of agentivityor outer cause is very low, i.e. the actor phrase kaze-ni 'by wind' refers to natural phenomenon without any agentivity. This type of example can illustrate the nature of earlier spontaneous passive.

\section{(14) Yamasuga nomi nara-nu koto-wo ware-ni yose sometimes true COP-NEG thing-ACC I-DAT compare ih-are-si kimi-ha tare to ka nu-ramu say-PASS-PST you-FOC who with Q sleep-SUBJ 'You were told what was not true about me. Who are you sleeping with?' (c.759 Manyooshyuu 564)}

What is often overlooked in previous research is semantic and functional characteristics of spontaneous passive. Due to the presence of verbal passive in Modern Japanese, all instances carrying the morpheme -(r)are are blindly considered as the passive, but they are in fact, as argued at length in Toyota (2011: 68-76), the middle voice rather than the passive. A seminal work by Kemmer (1993) presents various functions of the middle voice as represented in (15), and spontaneity (14h) is closely associated with the middle voice. The current state of the Japanese passive 
is, thus, a mixture between the old and new, i.e. the middle and the passive, with the middle voice fading away. In addition, one of the distinctive characteristics of the middle voice is so-called facilitativereading, i.e. "the event is conceived of as proceeding from the Patient [undergoer] byvirtue of an inherent characteristic of that entity which enables the event totake place" (Kemmer 1993: 147). The facilitative also includes potentiality, or "expression of intrinsic abilityof an object to undergo a particular process" (Kemmer 1993: 147). This also accounts for potential passive being fully functional in Old Japanese (cf. Table 2).

(15) a. Grooming/body care (e.g. 'wash', 'comb', 'dress', etc.)

b. Nontranslational/translational motion (e.g. 'stretch', 'turn', 'bow', 'climb up', 'walk', 'fly', etc.)

c. Change in body posture (e.g. 'sit down', 'kneel down', liedown', 'rise', etc.)

d. Self-benefactive (e.g. 'acquire', 'request', 'take for oneself',etc.)

e. Naturally reciprocal (e.g. 'meet', 'embrace', 'converse', etc.)

f. Emotion (e.g. 'be angry', 'grieve', 'be frightened', etc.)

g. Cognition (e.g. 'think', 'consider', 'ponder', 'believe', etc.)

h. Spontaneous (e.g. 'grow', 'sprout', 'recover', etc.)

i. Passive and impersonal

It is obvious that the passive in Modern Japanese still carries historical residues of earlier characteristics of the middle voice.As a result, the grammatical voice should be viewed in continuum, as far as the Japanese grammar is concerned. The middle voice is one of the most likely sources for the passive voice through the emerging importance of transitivity in grammar (cf. Toyota 2009b; 2012).However, the glossing in spontaneous passive (5) and potential passive (6) carries the passive marker. The argument so far clearly suggests that there are two constructions expressed by a single morpheme and the earlier examples (5) and (6) should be glossed with the middle voice marker as in (16) and (17), respectively.

Spontaneous passive
Mukashi-ga
shinob-are-ru
old.time-FOC remember-MID-PRS
'Memories of old time spontaneously come into my mind.' 
Junichi Toyota

\section{Potential passive \\ (17) Yuujinn-wa \\ kaigou-ni ik-are-nai \\ friend-TOP meeting-DAT go-MID-NEG \\ 'My friend cannot attend a meeting.'}

Note, however, this does not go without problems. Since historical changes are at constant flux and there are cases where it is not easy to detect a rigid distinction between two categories or constructions. Due to the long lasting influence of structuralism, our analysis often expects a clear-cut distinction between two categories, but this is not always the case and interferes with historical analysis. This ambiguous state is often termed as gradience, and it is an unavoidable nature in language, but these cases should be analysed internally and in comparison with other languages, but without interference of the grammar of other languages. The glossing problem often becomes a victim of this trend, but as shown above, there are many cases where analysis is inadvertently made obscure.

\section{Summary}

This paper has looked at cases where interlinear glossing may mislead our analysis, especially when analysing languages which are not familiar to researchers. It is a common practice in modern linguistics to identify a sharp distinction among categories, but this can lead to misunderstanding of what a construction really is. This is in part caused by influence of other languages, which are normally academically or politically dominant, but also by the lack of internal and typological analysis of a construction in question. The Japanese passive analysed here shows that there are two constructions, the passive and the middle, co-existing simultaneously expressed by the same morpheme. Among the five types of the passive, spontaneous and potential passive are better considered to fit in the category of the middle voice. Thus, the glossing for the passive voice can mislead researchers without competence in Japanese are led into believing that these are the passive voice.

Thus, the interlinear glossing should be used with more care and attention, and the same goes when one analyses examples with the glossing. Typological comparison will allow us to see a familiar construction in a new angle and this may aid us in analysing the data better. 
INTERLINEAR GLOSSING IN A HISTORICAL PERSPECTIVE: A CASE OF ...

\section{REFERENCES}

Anderwald, Lieselotte 2002. Negation in Non-Standard British English: Gaps, Regularizations and Asymmetries. London: Routledge.

Blake, N. F. 1996. A History of the English Language. Basingstoke: Palgrave.

Cheshire, Jenny 1998. 'Double negatives are illogical.' In Bauer, Laurie and Peter Trudgill (eds) Language Myths. London: Penguin Books, 113-122.

Hopper Paul J. and Sandra A. Thompson 1980. 'Transitivity in grammar and discourse.'Language 56, 251-339.

Jones, T. and A. Ereira 2005.Terry Jones' Medieval Lives (paperback edition). London: BBC Books.

Kemmer, Suzanne 1993. The Middle Voice. Amsterdam: John Benjamins.

Kinsui, S. 1997. 'The influence of translation on the historical development of the Japanese passive voice.' Journal of Pragmatics 28: 759-799.

Lowth, Robert 1763. Short Introduction to English Grammar: with critical notes ( $2^{\text {nd }}$ ed.). London: printed for A. Millar; and R. and J. Dodsley.

Matsumura, A. and K. Sakanashi 1986.MeikaiKotenBunpou (Grammar of Old Japanese). Tokyo:Meiji Shyoin.

Sanson, George 1946.An Historical Grammar of Japanese (revised ed.). Oxford: Clarendon Press.

Shibatani, Mayasoshi 1985. 'Passive and related constructions: a prototype analysis.' Language 61, 821-848.

Taylor John 2003. Linguistic categorization. Oxford: Oxford University Press.

Thráinsson, Höskuldur 1994. Icelandic. In König, Ekkehard and Johan van der Auwera (eds.) The Germanic languages. London: Routledge, 142-189.

Toyota, Junichi and Melisa Mustafović 2006. 'Grammatical Voice and TenseAspect in Slavic.' In Abraham, Werner and Larisa Leisiö (eds.): Passivization and Typology. Amsterdam: John Benjamins, 191-212.

Toyota, Junichi 2007. 'An adversative passive in English: in search of origins.' In Delbecque, Nicole and Bert Cornillie (eds.) The construction of meaning and the meaning of constructions: data-based approaches to transitivity, motion and causation. Berlin: Mouton de Gruyter, 143-169.

Toyota, Junichi 2009a.'Passive as a tense-aspectual construction revisited: a case of Germanic languages.' GroningerArbeitenzurgermanistischenLinguistik, spezial issue The passive in Germanic languages, 200-214.

Toyota, Junichi 2009b. 'Passive as an indicator of alignment change: in terms of transitivity.' GroningerArbeitenzurgermanistischenLinguistik, spezial issue The passive in Germanic languages, 41-52. 
Junichi Toyota

Toyota, Junichi 2011. The Grammatical Voice in Japanese: a typological perspective. Newcastle upon Tyne: Cambridge University Press.

Toyota, Junichi 2012. 'Dialect mixing as a language contact in the history of English.' In Trušník, R. et al. (eds) Theories and Practice: Proceedings of the third international conference on Anglophone Studies. Zlín, Tomas Bata University, 95-110.

Yamaguchi, A., R. Sakanashi, H. Suzuki, Y. Tsukimoto 1997. Nihongo no Rekishi (A history of the Japanese language). Tokyo: University of Tokyo Press.

\title{
Đunići Tojota
}

\section{INTERLINEARNO GLOSIRANJE IZ ISTORIJSKE PERSPEKTIVE: SLUČAJ GRADIJENCIJE U JAPANSKOM PASIVU}

\begin{abstract}
Sažetak
Rad se bavi slučajevima gde opšteprihvaćena praksa interlinearnog glosiranja može navoditi na pogrešne zaključke u tumačenju tipoloških podataka. Posebna pažnja se pridaje pasivu u japanskom, gde se pretpostavlja da sufiks ( $r$ )are obeležava pasiv. Međutim, zbog njegove višeznačne prirode, prethodna pretpostavka se može dovesti u pitanje. Razlog se može naći u istorijskom razvoju pasiva, koji upućuje na ostatke formiranja gradijencije. Preskriptivna gramatika je napisana delimično iz obrazovnih razloga, ali način na koji ona tretira gramatiku ponekad zasenjuje realnu unutrašnju strukturu.
\end{abstract}

Ključne reči: interlinearno glosiranje, pasiv, japanski jezik, tipologija, gradijencija, gramatikalizacija 